\title{
SURGICAL SITE INFECTION IN ORTHOPAEDIC SURGERY: CORRELATION BETWEEN AGE, DIABETES, SMOKE AND SURGICAL RISK
}

Leonardo Fisichella, Domenico Fenga, Michele Attilio Rosa

Department of Biomedical Sciences, Morphological and functional imaging, Section of Orthopaedics and Traumatology, Azienda Ospedaliera Universitaria Policlinico G. Martino, Messina, Italy

\section{ИНФЕКЦИЯ ОБЛАСТИ ХИРУРГИЧЕСКОГО ВМЕШАТЕЛЬСТВА В ОРТОПЕДИЧЕС- КОЙ ХИРУРГИИ: КОРРЕЛЯЦИЯ МЕЖДУ ВОЗРАСТОМ, ДИАБЕТОМ, КУРЕНИЕМ И ХИРУРГИЧЕСКИМ РИСКОМ}

Леонардо Физикелла, Доменико Фенга, Микеле Атиллио Роса

Департамент биомедицинских наук, морфологических и функииональных изображений, Секиия ортопедии и травматологии, Университеская больнииа, Поликлиника Г. Мартино, Мессина, Италия

\begin{abstract}
InTRODUCTION: Surgical site infection is a common complication after orthopaedic surgery. It can be associated with increased morbidity rate and social cost. The accurate identification of risk factors is essential so that strategies to prevent these potentially devastating infections can be developed. We have conducted this study to determine the possible risk factors for the surgical site infections. OвJECTIVEs: We aimed at finding exhaustive evidence concerning the potential risk factors for infections in orthopaedic surgery. Patients and Methods: Between October 2009 and December 2011, we identified 84 patients with a superficial and/or deep surgical site infection and compared them with 203 uninfected patients (control group), taken out from a series of 486 patients. We considered the following risk factors: diabetes, BMI $>30$, ASA Score of 3 or 4, smoking and age. RESULTs: The most frequently performed operations of the 287 examined patients were the knee and hip arthroplasties (n $=32,11.14 \%)$ and open fracture reductions $(n=178,62.02 \%)$. Staphylococcus Aureus was the most common identified pathogen $(n=63,75 \%)$. The analyses (preoperative and postoperative) of the infected patients showed them to have significantly high serum glucose levels in comparison with the control group (odds ratio $=8.7$ ). We found a significant high rate of infection in patients smoking for more than 20 years (67 patients, 79.7\%). The remaining variables (BMI, $\mathrm{OR}=2.21$; ASA score, $\mathrm{OR}=1.3$ ) showed no significant differences between the study group and controls. We also found a correlation between $>65$-year-old patients and infections at the surgical site (61 patients, 72.6\%). Conclusion: We found that there was correlation between diabetes, smoking and age as risk factors with the development of infection at the surgical site; other variables such as the ASA score and BMI are not relevant here (contrary to what is reported in literature). We believe that postoperative results can be improved considerably with a properly conducted antibiotic treatment, stringent glycemic control (achievable only with careful multidisciplinary management) and good compliance of patients.
\end{abstract}

Key words: diabetes mellitus, infection, surgical risk, osteomyelitis, smoke

Folia Medica 2014; 56(4): 259-263

Copyright (C) 2014 Medical University, Plovdiv

\section{РЕЗЮМЕ}

ВведЕниЕ: Постоперативная инфекция области хирургического вмешательства является одним из наиболее часто проявляемых осложнений при ортопедических операциях. Данное осложнение связано с повышением уровня заболеваний и социальных затрат. Точная идентификация факторов риска имеет важное значение ввиду возможности разработки определённых стратегий предотвращения данных потенциально разрушительных инфекций. Мы провели данное исследование с целью определить возможные факторы риска возникновения инфекции в области хирургического вмешательства. Цели: Целью данного исследования является поиск исчерпывающих доказательств, касающихся потенциальных факторов риска для возникновения инфекций в ортопедической хирургии. ПАциЕнты и методы: В период с октября 2009 г. до декабря 2011 г. мы определили 84 пациента с поверхностными и/ или глубокими инфекциями области хирургического вмешательства и сравнили их с 203 пациентами без инфекций (контрольная группа), набранных из группы обследованных пациентов общим количеством 486. Мы рассмотрели следующие факторы риска: сахарный диабет, BMI > 30, пункты 3 или 4 по ASA, курение и возраст.

РЕзультаты: Наиболее часто выполняемыми операциями среди 287 обследованных пациентов являлись артропластики коленного и тазобедренного суставов $(\mathrm{n}=32,11.14 \%)$ и открытая репозиция переломов

Article's history: Received: 11 Oct 2014; Received in a revised form: 3 Nov 2014; Accepted: 18 Dec 2014

*Correspondence and reprint request to: L. Fisichella, Department of Biomedical Sciences, Azienda Ospedaliera Universitaria Policlinico G. Martino, Messina

Azienda Ospedaliera Universitaria Policlinico G. Martino, Messina, Italy 
(n = 178, $62.02 \%$ ). Наиболее распространённым патогеном, выявленным нами, является Staphylococcus Aureus $(\mathrm{n}=63,75 \%)$. Анализы (предоперационный и постоперационный) пациентов с инфекцией показали, что у них наличествуют значительно более высокие уровни глюкозы в сыворотке по сравнению с контрольной группой $(\mathrm{OR}=8.7)$. Мы обнаружили значительно завышенный процент инфекции среди пациентов, куривших в течение более 20 лет (67 пациентов, 79.7\%). Остальные параметры (BMI, OR $=2.21$; результат по ASA, OR = 1.3) не показали существенных различий между группой пациентов и контрольной группой. Мы также обнаружили корреляцию между возрастом, превышающим 65 лет и инфектированием области хирургического вмешательства (61 пациент, 72.6 \%). ЗАключениЕ: Мы обнаружили корреляционную связь между диабетом, курением и возрастом в качестве факторов риска для развития инфекции области хирургического вмешательства; другие параметры, такие как результат по ASA и BMI не являются релевантными в данном случае (вопреки тому, что сообщалось в литературе). Мы считаем, что послеоперационные результаты могут быть значительно улучшены при правильно проведённом лечении антибиотиками, строгом гликемическом контроле (возможном только при строгом многопрофильном лечении) и аккуратным соблюдением терапевтического режима пациентами.

Ключевые слова: сахарный диабет, инфекция, оперативный риск, остеомиелит

Folia Medica 2014; 56(4): 259-263

(c) 2014 Все права защищены. Медицинский университет, Пловдив

\section{INTRODUCTION}

A surgical site infection in orthopaedic surgery is defined as an infection that occurs within 30 days of a surgery if no fixation devices have been implanted or within one year if a metallic device has been left in place. ${ }^{1}$ It is one of the most common post-surgical complications which is associated with increased morbidity rate and social costs. It is not always so easy to identify, classify and quantify a surgical site infection (SSI). To solve this problem, the USA CDC and some European projects (Hospital in Europe Link for Infection Control through Surveillance, HELICS and European Antimicrobial Resistance Surveillance Scheme, EARSS) have provided some definitions. There is a SSI surveillance system in the USA and North Europe which is not as yet operative in Italy. Research carried out in Italy has shown that the recognized epidemiologic features are similar to those depicted by the American system, the National Nosocomial Infections Surveillance System (NNIS), that represents an effective benchmark. The most recent NNIS studies have demonstrated that infection rate is $2.49 \%$ after open reduction of fractures, $1.67 \%$ after hip arthroplasty, and $1.47 \%$ after knee arthroplasty. ${ }^{2}$ The relevant literature on the effects of post-orthopaedic surgery SSI as well as on the associated risk factors is rather scanty in Italy. This can be accounted for by the lack of standardized reference values and to absence of cooperation among various specialists working on patient management during the recovery. The aim of the present study was to describe the independent risk factors due to the infection developed at the surgical site after orthopaedic surgery, in particular after open fracture reductions and prosthetic replacement of hip and knee.

\section{PATIENTS AND METHODS}

We performed this case-control retrospective study at the Orthopaedics and Traumatology Department of the University of Messina. All patients who underwent surgery from October 2009 to December 2011 were entered into the database. Table 1 shows the demographics and surgical procedures undergone by the study cohort. Patients with surgical site infections were selected after a rigorous examination and laboratory tests (ESR, RCP) and depending on whether they had positive culture results from the surgical wound swab; we also considered the $\mathrm{x}$-ray tests. We excluded patients admitted to the Emergency Room with exposed (and contaminated) surgical wounds as well as patients with negative culture results that were receiving antibiotic treatment for associated diseases. All patients underwent tailored antibiotic prophylaxis prior to surgery depending on the type and duration of the surgical procedure, as advised by the national guidelines of SIOT. ${ }^{3}$

Table 1. Demographics and surgery characteristics of 287 patients treated with orthopaedic surgery between October 2009 and December 2011

\begin{tabular}{lc}
\hline \multicolumn{1}{c}{ Sex } & 196 F ; 91 M \\
\hline Type of surgery & $\mathbf{n}$ \\
\hline Open reduction of fractures & $178(62 \%)$ \\
Knee / Hip arthroplasty & $32(11 \%)$ \\
Others & $77(27 \%)$ \\
\hline
\end{tabular}


The correlation between a surgical site infection and risk factors was analysed using the odds ratio. Multivariate logistic regression analysis was used to identify the independent risk factors. We identified 84 patients with SSIs. 203 patients had no infection based on the NNIS parameters, with random sampling. Database was compiled by filling out prearranged models which included surgery type, risk factors, signs and symptoms of infection of the wound and isolated microorganisms. The risk factors were selected after a thorough survey of the international literature previously reviewed by the authors.

\section{RESULTS}

Out of a total of 287 patients treated between October 2009 and December 2011, we identified 84 surgical site infections. Based on the NNIS classification we divided these into three categories: superficial SSI (33 patients, 39\%), affecting only the skin or the tissue around the wound; deep SSI (37 patients, 43\%), which affected the fascia or the soft tissues; and organ/space SSI (14 patients, 17\%), which involved an open anatomical space during the surgery besides the incision, including osteomyelitis and empyema. ${ }^{2}$ Each patient, based on the internal protocol, was subjected to clinical examinations on days 7 (medication), 14 (desuture), 30 (X-rays control), and 60 (check-up) of operation. During the desuture 49 patients showed undeniable signs of surgical site infection (skin rush, swelling, heat, pain, fever, and inflammation indexes increase); in 21 patients these signs were already manifested after 7 days. In 14 patients the infection was manifested 30 days after surgery, while in 203 patients there was no infection. The risk factors associated with an increase of risk of SSI are shown in Table 2.

The results suggested that obesity ${ }^{4}(\mathrm{BMI}>30)$ and disabling diseases ${ }^{5}$ (ASA score of 3 or 4 ) showed no distinctive correlation with the onset of SSI, in contrast with data reported in literature. There was an increase of the effect of surgical site infection in diabetic patients (without any difference between

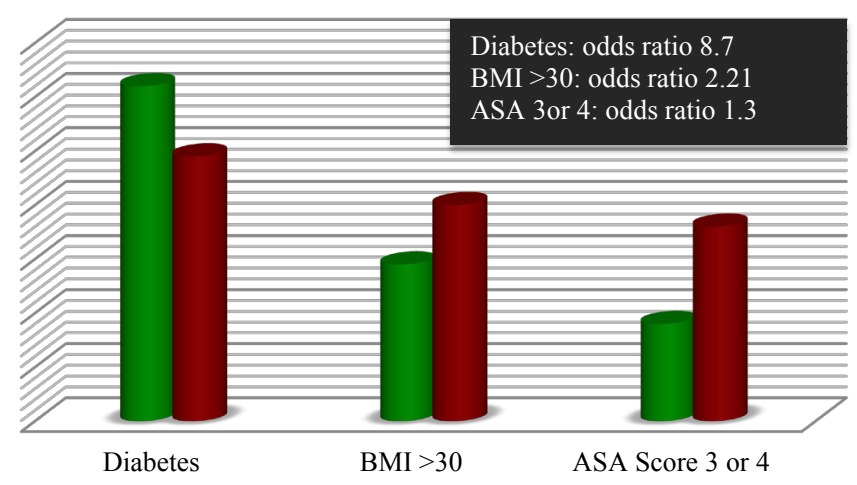

Figure 1. Risk factors and odds ratio.

type 1 and type 2 diabetes); the glycemic serum level was elevated both pre- and post-operatively (Fig. 1). ${ }^{6}$ Furthermore, risk factors highly predictive of infection of surgical wound were age ${ }^{7}(>65$ years old) and smoking ${ }^{8}$.

\section{DISCUSSION}

The aim of the present study was to find a correlation between some of the patient-related risk factors with the development of SSI in patients subjected to orthopaedic surgery.

Studies have shown that diabetes has commonly been associated with the development of infection, regardless of the type of diabetes.

It is clear that there are alterations considered as expression of a defect of wound's healing, as illustrated by literature; those concern phagocytosis, chemotaxis, blood vessels adhesion and bactericidal activity of neutrophil granulocyte, collagen and protocollagen synthesis, capillary neoformation and fibroblast proliferation. Robson and Heg-

Table 2. Univariate comparison of individual risk factors with and without surgical site infection following orthopaedic operation

\begin{tabular}{lccc}
\hline \multicolumn{1}{c}{ Patient level characteristics } & No of patients with SSI & No of uninfected patients & Odds Ratio \\
\hline Body Mass Index $>30$ & $29(34 \%)$ & $40(20 \%)$ & 2.21 \\
Diabetes & $62(74 \%)$ & $49(23 \%)$ & 8.7 \\
ASA class III or IV & $18(21 \%)$ & $36(17 \%)$ & 1.3 \\
Age $>65^{*}$ & $61(73 \%)$ & - & - \\
Smoke* & $67(80 \%)$ & - & - \\
\hline
\end{tabular}

*Variables evaluated only for the infected group; ASA - American Society of Anesthesiologists. 
gers studied the infections of surgical wounds in diabetic patients evaluating the bacteria in the presence of hyperglycemia. ${ }^{9}$ Results have shown that Gram-positive bacteria are able to survive in a hyperglycemic serum, while Gram-negative bacteria develop with some difficulty. Furthermore, as it has been shown by NJ Davidson et al., it is possible that non-enzymatic glycosylation, favoured by an excess of glucose, modifies the function of plasma proteins, influencing delay of the wounds' healing and predisposing them to infection. ${ }^{10}$ The diabetic patient is more susceptible to the development of infections, as the high levels of glucose in blood can weaken the patient's immune system. Moreover, complications connected with diabetes, as neuropathic and vascular diseases, increase the organism's vulnerability to infections. ${ }^{11}$

Reports in the literature show that smokers and patients over 65 years old are statistically more susceptible to infections of the surgical path. ${ }^{12}$ Smoking causes hypoxia of the peripheral tissues - it reduces the aggression capacities of the immune system, favouring the growth of infections. In addition, in smoking patients we can see a delay of the sediment of collagen in the surgical site, so that it is not possible to guarantee the tissue proper reparation.

A third possible mechanism is that smoking affects the metabolism of the connective tissue, altering the equilibrium between protease (enzymes that degrade proteins) and anti-protease, producing a deterioration of the connective tissue. ${ }^{13}$ However, a limitation of these studies is that phrases such as "regular cigarette smoking" and "active smoker" are not always clearly defined. To find properly how the use of tobacco contributes to the risk of SSI, it would be better to adopt standardized definitions of the smoker's routine and that those have to be used for studies that could identify controls to avoid independent variables.

With increasing age it is common to find vitamin $\mathrm{C}$ deficiency, essential element for the development of collagen, that connected to circulatory disease (venous stasis), immune defence system disease and lack of hygiene, it contributes to the growth of an infectious process on the patient. ${ }^{7}$

We found no correlation in our study between other factors (obesity and an ASA score of 3 or 4) and increased risk of SSI. Reports in the literature have demonstrated that in overweight patients there is an infiltration of inflammatory cells in adipose tissue, which does not happen usually. ${ }^{14}$ It has not been considered the adaptation of the antibiotic drug dose in relation to the body weight. ${ }^{15}$ Moreover, it has been shown that a longer pre-operative recovery, usually caused by the seriousness of the disease and/or co-morbidity, is responsible for an increased risk of SSI. ${ }^{5}$

\section{CONCLUSIONS}

The results of this study suggest that diabetes is a risk factor for SSI, alongside with other variables such as age $>65$ years and smoking; it does not preclude other factors we analysed, such as obesity or ASA score of 3 or 4, from triggering development of SSI. Although it obviously is impossible to avoid completely the risk of developing SSI, if we take into account the high economic burden, besides the greater morbidity and mortality rates, these infections can cause, it is highly important that we make use of all available instruments to reduce their occurrence to a minimum - even a small reduction of their incidence can bring about a considerable economy of resources that can otherwise be used for implementing other prevention programs.

The appropriate measures to adopt have to start from a proper asepsis, passing through proper surgical procedures, appropriate knowledge of prophylaxis and health care procedures, wise use of any novel resources for the prevention (suture stitches with antibiotic solutions, stents, medicated catheters, etc.), associated with a meticulous control of pre- and post-operative glycemic values. It is clear that a good compliance of patients is always important. Indeed, a lot of patients are dismissed after a short time of convalescence, even before complete healing of their surgical wound.

The lack of optimal protocols for home medication and implementation of healthy and sanitary rules, such as reduction of body weight ${ }^{16}$ and smoking cessation, make it necessary that patients and their relatives should make a lot of efforts.

At discharge patients should be instructed to properly tend to their surgical wounds and to be able to recognise the signs and symptoms of infection and to contact qualified specialists for any kind of problem.

It is also possible that in trying to prevent an infection process after surgery patients may resort to an indiscriminate use of antibiotics. Researchers have recently examined the problem so that proper guidance could be provided to doctors in finding the most appropriate antibiotic therapy in terms of times and doses. ${ }^{17}$ 


\section{REFERENCES}

1. Awad SS, Palacio CH, Subramanian A, Byers PA, Abraham P, Lewis D, et al. Implementation of a methicillin-resistant Staphylococcus aureus (MRSA) prevention bundle results in decreased MRSA surgical site infections. Am J Surg 2009;198:607-10.

2. Horan TC, Culver DH, Gaynes RP, Jarvis WR, Edwards JR, Reid CR. Nosocomial infections in surgical patients in the United States, January 1986-June 1992. National Nosocomial Infections Surveillance (NNIS) System. Infect Control Hosp Epidemiol 1993; 14:73-80.

3. SNLG. Antibioticoprofilassi perioperatoria nell' adulto. http://www.snlg-iss.it/cms. September 2008.

4. Waisbren E, Rosen H, Bader AM, Lipsitz SR, Roger SO Jr, Eriksson E. Percent body fat and prediction of surgical site infection. J Am Coll Surg 2010;210(4):381-9.

5. Khan M, Rooh-ul-Mugim, Zarin M, Khalil J, Salman M. Influence of ASA score and Charlson Comorbidity index on the surgical site infection rates. J Coll Physicians Surg Pak. 2010;20(8):506-9.

6. Richards JE, Kauffmann RM, Zuckerman SL, Obremskey WT, May AK. Relationship of hyperglycemia and surgical-site infection in orthopaedic surgery. J Bone Joint Surg Am 2012;94(13):1181-6.

7. Kaye KS, Schmit K, Pieper C, Sloane R, Caughlan KF, Sexton DJ, Schmader KE. The effect of increasing age on the risk of surgical site infection. J Infect Dis 2005;191(7):1056-62.

8. Sorensen LT, Karlsmark T, Gottrup F. Abstinence from smoking reduces incisional wound infection: a randomized controlled trial. Ann Surg 2003;238(1):1-5.
9. Robson MC, Heggers JP. Effect of hyperglycemia on survival of bacteria. Surg Forum 1969;20:56-7.

10. Davidson NJ, Sowden JM, Fletcher J. Defective phagocytosis in insulin controlled diabetics: evidence for a reaction between glucose and opsonising proteins. J Clin Pathol 1984;37(7):783-6.

11. Ross HM (2008). Common infection in Diabetes. http://diabetes.about.com/1w/Health-Medicine/ Conditions-and-diseases/Common-Infections-inDiabetes.htm. July 29, 2008.

12. Sørensen LT. Wound healing and infection in surgery. The clinical impact of smoking and smoking cessation: a systematic review and meta-analysis. Arch Surg 2012;147(4):373-83.

13. Sørensen LT, Hemmingsen UB, Kirkeby LT, Kallehave F, Jørgensen LN. Smoking is a risk factor for incisional hernia. Arch Surg 2005;140(2):119-23.

14. Fain JN. Release of interleukins and other inflammatory cytokines by human adipose tissue is enhanced in obesity and primarily due to the nonfat cells. Vitamins and Hormones 2006;74:443-477.

15. Toma O, Suntrup P, Stefanescu A, London A, Mutch M, Kharasch E. Pharmacokinetics and tissue penetration of cefoxitin in obesity: implications for risk of surgical site infection. Anesth Analg 2011;113(4):730-7.

16. Thomas EJ, Goldman L, Mangione CM, Marcantonio ER, Cook EF, Ludwig L, et al. Body mass index as a correlate of postoperative complications and resource utilization. Am J Med 1997;102:277-83.

17. Classen DC, Evans RS, Pestotnik SL, Horn SD, Menlove RL, Burke JP. The timing of prophylactic administration of antibiotics and the risk of surgicalwound infection. New Engl J Med 1992;326:281-6. 